\title{
Teachers Talking in Very Young Learners Immersion Class: How They Did It
}

\author{
Farouq Aji Subroto ${ }^{1}$, Yazid Basthomi ${ }^{1}$, Utari Praba Astuti ${ }^{1}$ \\ ${ }^{1}$ Pendidikan Bahasa Inggris-Universitas Negeri Malang
}

\section{INFO ARTIKEL}

\section{Riwayat Artikel:}

Diterima: 18-12-2019

Disetujui: 14-12-2020

\section{Kata kunci:}

very young learner immersion class; teacher talk; siswa usia dini; kelas imersi; pembicaraan guru

\author{
Alamat Korespondensi: \\ Farouq Aji Subroto \\ Pendidikan Bahasa Inggris \\ Universitas Negeri Malang \\ Jalan Semarang 5 Malang \\ E-mail: farouqajisubroto@gmail.com
}

\begin{abstract}
ABSTRAK
Abstract: This research aimed to describe the language used by the teachers namely teacher talk in VYL English Immersion class whose students' age ranges from three to six years old and to describe how the language was used effectively in the class. The results showed that there were four types of teacher talk used frequently to help the teachers teach effectively in the class namely (1) giving directions, (2) giving information, (3) asking questions, and (4) praising and encouraging. Those four talks did not work alone in the class; the teachers also use gesture and demonstration to accompany the talks.
\end{abstract}

\begin{abstract}
Abstrak: Penelitian ini bertujuan untuk mendeskripsikan tipe-tipe bahasa Inggris yang digunakan guru dalam konteks pengajaran bahasa Inggris pada kelas imersi dengan siswa berusia antara tiga sampai enam tahun dan menjelaskan bagaimana tipe-tipe bahasa tersebut digunakan secara efektif di kelas. Hasilnya, terdapat empat tipe bahasa yang sering digunakan guru untuk menyampaikan materi, yakni (1) pemberian arahan, (2) pemberian informasi, (3) pertanyaan, dan (4) pujian dan dorongan. Keempat tipe bahasa tersebut tidak digunakan secara independen di kelas. Guru juga menggunakan bahasa tubuh serta demonstrasi kegiatan saat menggunakan keempat tipe bahasa tersebut.
\end{abstract}

Sending their kids to ECE service, the parents also expect something else than just preparing them to go to elementary school, which is the main goal of ECE services (Chang, et al., 2006) since it is proven to reduce grade repetition in elementary schools. They expect their children to learn another language, which is English language. This also becomes one of the reasons why nowadays a lot of parents send their children in ECE services that provide English language teaching (Jazuly \& Indrayani, 2018). They believe that the sooner they introduce their children a new language, they will learn it faster and better. The idea is actually good since teaching a second language to children in early ages is deemed to be effective. It is supported by the Critical Period Hypothesis (CPH): a biologically determined period of life when language can be acquired more easily, that is between the age of two years and early teens (Brown, 2000). CPH also believes that if children learn a new language during that period, they will possibly be able to achieve the native-like language skill, especially accent (Hrda, 2017). Unfortunately, in 2013 curriculum, English is actually excluded in this level. But because of the increasing demand from the parents, Jazuly \& Indrayani added in their study, most kindergartens add English as one of their subjects because they are allowed to expand the curriculum.

Nevertheless, most of ECE teachers do not have pre-service training as English teacher or vice versa. This is because there is no pre-service training in Indonesia that specially prepares teacher to teach both English and very young learners. Again, with the absent of English subject in the curriculum, there is no exact syllabus as a reference to what materials there are to teach for these very young learners. Thus, the teachers need to design all the materials from scratch in which it is clearly not the area of Indonesian ECE teachers to deal with. As a result, the teachers thought some possibly useful materials such as daily expressions and simple vocabulary and taught the students (Nurhayati, 2014). In addition to the lack of syllabus and teaching materials, the teaching was conducted based on translation where the use of L1 was dominant. This method led to students' inability to the use of the language fluently. Consequently, the use of mother tongue in the EFL classroom started to be seen as uncommunicative, boring, pointless and irrelevant (Harmer, 2002). In other words, Indonesian ECE services might have to prepare more if they want to include English since starting age is not a sole factor for the success of the learning. The qualified teachers (Fenclova, 2004; Jezkova, 2011) and sufficient target language exposures are also imperative in the success of the learning of the very young learners. 
To the best of my knowledge, immersion is a way that is proven to be effective in exposing a student with sufficient target language. There were 71 Cuban immigrants who had lived in California around five years aged from seven to 19 years and 30 American-born children. The result was although none of the Cubans were considered a native speaker, but many of them were judged to speak with near-native pronunciation. Similar findings prevailed in an investigation of 39 migrants born in Russia who had arrived in the united stated aged from four to 44 years.

Thompson's finding was that the migrants' age on arrival in an English-speaking environment 'was the best indicator of the accuracy of their pronunciation in English. Interestingly, none of the Thompson's subjects was rated as being at native-speaker level in terms of accent. However, subjects who had arrived in the United States at age ten or younger were judged to have only slight foreign accents, with the best ratings of all being allocated to the two subjects who had arrived at age four. (Singleton \& Ryan, 2004).

Both studies use subjects who were immigrants to United States. It means the subjects were immersed in an English speaking area and they needed to speak English in order to survive. Even though none of the subject was considered as a native speaker, many of them spoke with near native pronunciation.

From the school setting, immersion methodology started around mid-1960s in the Canadian St. Lambert School of Quebec. French is the official language in this area, for what high levels of proficiency in the language were required for the survival of the economic industry. Some children studied French at school, following a grammar and memorization strategy, what limited the communicative skills children could achieve on the language. Some worried parents organized and got advice from experts in bilingualism programs and the school staff members to change the situation. The result was the implementation of a complete new method in which from nursery, children' schooling was entirely in French, introducing English lately in grade 2. Due to the efficacy of the immersion program, it rapidly expanded to the other areas and countries.

The application of immersion methodology in St. Lambert School seems to run very smoothly. To be kept in mind, French was already the official language in this area. So, it could be their second language or at least a lot of adults have mastered French since it is one of crucial factors to survive in the industry. In short, they might just need to switch their (school staff members') language from English to French. In my opinion, applying the same methodology in Indonesia to learn English would be a different story. English is not an official language here nor have many adults mastered it. In a survey conducted by EF (2018) namely EF EPI (English Proficiency Index), Indonesia ranks 51 out of 88 countries around the globe, belonging to low category. It could mean that a lot of preparations need to be made by ECE services if they want to apply immersion methodology in their schools. At least, the school staff members must be fluent in this English Course, so the immersion-like situation can be created.

Because of the exclusion of English in 2013 curriculum, there are no ECE services that are known to be qualified to teach English in Indonesia, let alone apply immersion methodology. However, there is one institution in Indonesia that officially released its new set of levels in 2009 that deals with teaching English to students aged 3 - 6 years. The institution is famous for its VYL program (henceforth referred to as SS). In this level, the institution really goes all-out; from 2009 until now, SS level materials (e.g. books, flashcards, realias, and IWB (Interactive White Board) materials) have been renewed 3 times. There are four books for children aged 3, 4, 5 and 6 namely book 1, 2, 3 and 4 respectively. Most of the teachers are the graduates from English departments and most of them have passed TKT-YL (Teacher Knowledge Test of Young Learners) by Cambridge, which testifies their knowledge in young learners.

Another reason for the institution to be brought into this present study is because, from the pilot study, it is known that the institution offers something that most of the existing ECE services in Indonesia do not, that is an immersion-like teaching situation. During a sixty-minute class with very young students or learners, none of Indonesian sentences, phrases or even words had been uttered by the teacher. As a matter of fact, most ECE services in Indonesia are using mother tongue when teaching English subject (e.g.; in Salatiga (Astika, 2012), in Yogyakarta (Nurhayati, 2014), in Kudus (Danuatmaja, 2016), etc). That is why we see this phenomenon as unique and worth researching.

Although the previous studies about immersion were able to identify the effects of immersion program on student language development, they were not able to look into how the teachers actually use the L2 to deliver the lesson and what specific efforts they make to ensure students' full understanding. In every lesson, teacher talk that takes approximately two thirds of a lesson has been highlighted for its crucial importance in classes with various functions. Class objectives are achieved through communication between teacher and students (Seong, 2006), and teacher talk has an important role of scaffolding. With the recognized importance, it has gained attention from researchers, and studies have been conducted on both quantity and quality of teacher talk to find out how teacher talk effectively facilitates learning and communicative interaction. For example, past research has shown that teacher talk plays a crucial role in aiding effective teaching itself and in establishing rapport with students for emotional scaffolding (Rosiek, 2003).

In Indonesia, studies on teacher talk also gained some attention from researchers, and studies from various research settings had been done, such as; in the primary schools (Pujiastuti, 2013; Kristianingsih, 2011), in junior and senior high schools (Febiarachmah \& Susanto, 2017; Pangesti, 2016; Nasir, Yusuf, \& Wardana, 2019) and even in universities (Meida \& Fadhly, 2018; Sofyan \& Mahmud, 2014). The results slightly varied between the three different settings. In primary schools giving 
direction and lecturing were the first and second dominant types of teacher talk. In junior and senior high schools asking question became the runner up with the same type on the first. While in universities, asking question appeared to be the most frequent teacher talk type in the discourse. However, little attention has been given to ECE setting. Until now, only a few had researched teacher talk in ECE context, one was written by Astika (2012), who turned out to describe teacher's move based on Kim's and Elder's teacher's move framework.

Therefore, studies of teacher talk in L2 immersion ECE programs for which understanding of L2 exposure are the primary goals are necessary. Although the results of the previous studies do not differ much from one level to another, the similar study on ECE programs might result differently as the students have far different characteristics from those of the others and Flanders has also argued that teachers of different grade levels and of different subject matter will produce radically different patterns of verbal behavior. That is why this study is of great importance to shed a light on the teacher talk in L2 immersion ECE service. Further, this study will be possible to be done in SS level classes since this course has been practicing immersion methodology for about ten years in this level and the students of the program are three to six year-old kids. This present study tried to figure out the target language produced by the teachers.

After figuring out the types of teacher talks that were used in the classes we also wanted to know how the talks were used in the class because the mother tongue is not used in SS classes. Reilly \& Ward (2017) state that there are some ways of avoiding the mother tongue in teaching VYLs; they are gesture, using international English which is more like common English words, using English words that are similar to mother tongue and English hats which are actually constantly applied routines (Shin, 2006) that encourage students to use English. All these four techniques, they argued, are very powerful when it comes to teaching three to six year old students using a target language. However, they also argued that the avoidance of mother tongue might take too much time to make students get the message and still there is a chance that teachers fail in doing it.

In another experimental research with the subjects of very young learners aged 5 comparing two groups that were taught words using picture and taught words with accompanying gestures. The results showed that the use of gestures help students memorize a target language (Tellier, 2008). In this research, gestures are proven to influence the students not only to understand vocabulary items being taught but also to help students produce the vocabularies because in learning vocabulary, she argued, gestures reproduction also acts as a motor modality that leaves a richer trace in memory so when the students need to use the words having been taught before, it is easier for them to find a path to the words in their brains.

Not only gestures, but modeling, explaining and demonstrating are also beneficial for young learners. They provide accurate and useful representation of information and make the cognitive process of understanding certain knowledge easier since it is a visual expression of the topic (Salisu \& Ransom, 2014). Apart from that, Mr Klipstein, a first-grade teacher (Silverman \& Hartranft, 2015), showed how important breaking down language instructions is in teaching very young learners. He breaks down the instructions step by step and uses pictures and non-verbal clues to remind the students what to do in each step. From this, it can be seen that he wants to make sure every steps is done correctly by using the target language carefully. That is why the instructions are broken down and he reminds the students what to do each step because VYLs' attention span is really short and they might forget what to do next.

The other strategy is the use of puppets in English young learner class to help teachers in using their language and create a funny atmosphere (Caganaga \& Kalmıs, 2015). Teachers can use puppets to model simple dialogue frequently (Majaron, 2011) so the students could learn the skill by simply watching it. When teachers feel that students have learned something, it could also be used to increase dialogue effectively (Mishina \& Wallace, 2004) since students become more comfortable and open up with the help of puppets.

There must be a lot of language produced in VYL immersion class but to know which one is produced and to know how it is used effectively in the class would be great information for other VYL teachers to deal with their VYL students and to be adapted with their teaching environment.

\section{METHOD}

A qualitative research methodology was chosen for this study in the form of a descriptive study. It basically describes the existing phenomena as accurately as possible (Atmowardoyo, 2018). The reason why this design was used was that because we wanted to explore how the teachers fully used English language strategically to teach very young learners and ensure the students' understanding of the language and the qualitative research methodology (Bryman, 2008) was best suited for this research since it aimed to observe the process by which knowledge was created and handled within specific social environment, very young learner immersion classes in SS class.

This study was conducted in an English course in Sidoarjo in its two SS classes. Currently, there were 10 out of 14 teachers who had SS classes to teach and two out of those ten were SS specialists (henceforth referred to as T1 and T2). Both had passed TKT-YL and since the new version of SS (3.0) had just been released, both had been joining extensive amount of trainings regarding to SS level in the headquarters. Both were of good qualities as SS teachers and admitted as the bests in the center, which was the reason why they were chosen to be the specialists. 
We had requested them to participate in this study and explained that an SS class lesson was used as sources of data for this study. Both agreed and were willing to participate in this study since the results of this study might be able to provide feedback for them and be a beneficial reference for other SS teachers. Regarding which SS levels and classes this study used, it was really out of my jurisdiction as a researcher. This study used any SS classes that the specialists had by the time the data were collected and/or any classes of the two teachers that the Head teacher allowed to be observed.

The subjects were individually interviewed using semi structured interview to answer the problems of the study of the research. The interview was done to dig teachers' perspective on how they use English language in class deeply, to find out what teacher talk the teachers think they used when teaching SS levels, how they used it effectively in the class and professional developments they had attended to support teaching very young learners.

The individual interview was chosen instead of group interviews so that I, the researcher, could deeper in each interviewee's experience. It was also done to give guarantee to the interviewees that their answers were confidential and they were not be judged by their answers by the other teacher. Their answers were personal and confidential. Another reason was that the teachers were packed with tight teaching schedule that inviting both in one session was unlikely to happen. The interview was transcribed then showed to the participants that they checked and rechecked their answers. Another data were two videos from each teacher's class. The video recording was done to crosscheck the interview answers with what really happens in the class. Besides, the videos were also used to see how teachers really dealt with the very young learners in using English language and to observe how the students responded to the teachers as indication whether the students understood the language.

This study wanted to make sure that the teaching processes were uninterrupted and happened like they would. Therefore, all teachers' and students' behaviors in class would be natural. To make sure that happens; a small camera was installed and hidden in a room to record the 60-minute lesson. The video recording was chosen as it eases the process of collecting data when conducting a study in a preschool setting, the videos can be slowed and repeated as often as needed to code the teacher talk. After the videos from both teachers were obtained, all teachers' language was transcribed and showed to the teachers. When the participants consented with the interview and video transcriptions, they were treated as research data.

In relation to theory, this study was deductive in attempting to confirm if a theory of immersion learning walked along with theories of interaction analysis and teaching strategies applied in this phenomenon. On the other hand the study was inductive in its aim to develop and widen the understanding of how immersion class was applied in Indonesian very young learner class.

The very first step in data analysis started from the interview. The interview was recorded as a document for this research. The recorded interview was then transferred into transcript. The results of the interview were triangulated with the videos from both teachers and some documents that the course has related to SS teaching. The videos were transferred into transcript. Coding process was done by looking closely at the transcript and labeling teachers' utterances with related teacher talk type next to them and it was indexed in Teacher Talk table. Students' response, if necessary, or any incidents would be written under 'notes' column. To get the percentage of each teacher talk type used in the classes, the frequency of each teacher talk type was counted and the results were written in Percentage of Teacher Talk table (see Appendix 7).

All data were further analyzed. From the interview, similar responses regarding teaching strategies and teacher talks from the participants were chosen to represent data. This was then cross-checked with the video recordings and or transcripts to see and clarify what really happens in the classes. Finally, the data are triangulated when we find topic similarity from two or more source data.

\section{RESULTS}

For the purpose of this research, we approached two teachers who were SS specialists in order that we could observe their SS classes. As mentioned in the previous chapter, by observing means that we recorded them teaching their class using a hidden action camera so that the students did not know if they were observed and that they would behave and respond to the teacher's instructions naturally. By the time the data were taken, both teachers were teaching SS 1 class whose students are three-year old kids. We requested them to observe the classes and both allowed me to do that.

The results of the observations were two videos which were then transcribed and labeled with the correct types of teacher talks as described in Chapter two. Since the classes being observed were VYL classes, chunks and single words which might be misinterpreted were used a lot in the classes and to avoid mistakes in labeling each utterance, we had clarified the transcriptions as well as the teacher talk labels for each utterance to the corresponding teachers. For the purpose of confidentiality of the subjects, each teacher would be referred as T1 and T2.

Besides the video transcriptions, this research had two other main sources of data which were interview with the teachers regarding the use of teacher talks as well as their strategies when teaching their classes and document overview related to the VYL or SS teaching strategies. The three mentioned sources were combined to find the answers for the problems of study of this research. 


\title{
Words to Sentences The Teachers Uttered: The Talks
}

Before the interviews were conducted, both teachers were given a handout containing descriptions of types of teacher talks. We, the teachers and I, then had a discussion in order to have the same understanding of them. From the interviews, the teachers had different opinion of which type they use most when they teach SS class.

From the interview, T1 believes that she uses a lot of praises and encourages when teaching SS class. She argued that VYLs respond positively towards them and the praises and encourages she meant should be specific. She also gave examples of how to give specific praises as stated below;

So, definitely praises and encourages because students respond positively towards phrases and encourages. And because the opposite is contra productive I'm afraid because that happened to students of mine with the sad house, it's definitely not working, not working. So praises and encourages should be incorporated in like every time. But, ideally, from the training that I had attended, it should be like clear, the praises, like "oh this is a good job you did, this is really good." But I sometimes forget to mention the specific praises. (T1 - excerpt 12)

In addition to the praises and encourages, she also told me that she uses a lot of questions in her class. She assumes that her students, even though they are very young, know something. This type of talk, she said, was the second mostly used after the praises and encourages. According to her, by asking questions she can also check her students understanding of what she has said.

$\mathrm{T} 2$, on the other hand, believes that she deals with students feeling a lot when she teaches her SS class. She does that to make sure that her students feel secure in the class and when the students do feel secure in her class, they will, according to her, start to open up a little bit and become more attached to her as stated below.

\begin{abstract}
So, whenever they come to the class, I ask how they are feeling, what they did before they come to the classroom, asking about what they like and dislike, simple things like that. So, like asking them like is that your favorite teacher or are those your favorite shoes? And other things like that. Once they feel like my teacher like my stories they will start to open up little bit and become more attached to you, and that way, they'll be more comfortable being with you in the classroom. And then of course number 2 praises and encourages because you know kids like to feel, not accepted, what is it? Respected. Even though they very young they love to be praised; "oh you're so good, good job". (T2 - excerpt 12)
\end{abstract}

In a part of interview above $\mathrm{T} 2$ also added that she uses a lot of praises and encourages in her class. The reason why she does that is not far different from what T1 said; it was because VYLs love to be praised but she did not mention how praises and encourages should be done whether they should be specific or general. The example of praises she gave was "oh you are so good, good job."

The interview results from the teachers have one in common, which is the extensive uses of praises and encourages even though not all teachers position them as the first place among the seven teacher talk types. The observation results also rhyme the same regarding the use of praises and encourages. They were used a lot but again they are not the mostly used teacher talk type. The one that was mostly used was giving directions, as we can see in the chart below.

Tabel 1. The Percentage of Types of Teacher Talks Made

\begin{tabular}{|c|c|c|c|c|}
\hline \multirow[b]{2}{*}{ No } & \multirow{2}{*}{ Teacher Talk Type } & T1 & T2 & \multirow{2}{*}{ Percentage of Each Type } \\
\hline & & Percentage & Percentage & \\
\hline 1 & Dealing with feeling & $0.96 \%$ & $1.58 \%$ & $1.37 \%$ \\
\hline 2 & Praises and encourages & $12.96 \%$ & $14.23 \%$ & $13.79 \%$ \\
\hline 3 & Using ideas of students & $2.88 \%$ & $1.83 \%$ & $2.19 \%$ \\
\hline 4 & Asking questions & $27.2 \%$ & $13.06 \%$ & $17.90 \%$ \\
\hline 5 & Giving information & $25.28 \%$ & $29.45 \%$ & $28.02 \%$ \\
\hline 6 & Giving directions & $27.68 \%$ & $37.02 \%$ & $33.83 \%$ \\
\hline 7 & Criticizing student behavior & $3.04 \%$ & $2.83 \%$ & $2.90 \%$ \\
\hline
\end{tabular}

As we can see on the table above the most used type of teacher talks was giving directions. From the videos of both teachers, we figured out that $\mathrm{T} 1$ and $\mathrm{T} 2$, when they tried to set up activities, were using a lot of directions in order to get the students to understand and it often happened that a same instruction was repeated for more than three times until the students got the hang of it. 
As an example in T2 SS class when she tried to make the students sit after the students had finished writing (by tracing) their names on the board. She called the students who still stood up "come here Valerie, Rega, Melody." then she directed them by saying "and then sit down." After that the same direction was repeated for three times; "sit down", "sit down", and "okay, sit down". So, in total she did it four times to have the students sit down.

It happened again when she wanted to change an activity; she wanted the students to stand up after conducting a drill activity by sitting on the floor. She used five imperative sentences containing phrase "stand up"; 1. "Okay, now stand up again", 2. "Stand up again", 3. "Stand up", 4. "Stand up", 5. "Stand up". We considered those utterances as five instead of one since there was a pause between each of them and T2 only repeated the utterance when she had to, she stopped using the same instruction when the students responded accordingly. Again, T2 had agreed with the labeling after we showed her the transcription. The same phenomenon also occurred in T1 when she taught her class, but the repetition was only done for twice or maximum three times for one same instruction, for example when she wanted her students to help find pink book pictures in a book and counted them, she used "help" three times until the students found the pictures in the book.

Another interesting finding is about some same words used when T1 and T2 taught their classes. Sometimes the words can have different functions, which could be misinterpreted by me as the researcher. That's why, we had crosschecked with T1 and $\mathrm{T} 2$ if the labels we gave for that case were right or wrong. The reason why it happened turned out to be related to strategies the teachers applied in their teaching and it will be discussed further in the next sub-chapter.

\title{
How They Did it: The Strategies
}

In teaching their three-year old students both teacher, based on what we observed from the videos, had similar patterns in using their language in their teaching activities. Those similarities were also mentioned during the interviews. It turned out that they were kind of strategies of the use of language that T1 and T2 always apply in their VYLs classes to make sure their students understand their language and respond accordingly.

During a sixty-minute lesson, the language produced was simple; expressions used sometimes only contained one to three words, for example; "cross legs", "not finished, "sad house?" etc. Sentences used were also limited to simple sentences, there were no complex sentences. A few compound sentences used during the lesson but the teachers sometimes broke them down in such a way that the students could understand the sentences

For instance; after T2 instructed "Okay, now put your name to the happy house.", the students seemed to be confused with that instruction then T2 broke it down to be "put your name there"(pause) "to the happy house". Then the students started to put their name in the house. For information Happy house here was a part of routines that this course, at the time this study was done, applied as a rule for three-year old classes; if students behave well they can stay in the house until going home and be rewarded with stickers and if they do the otherwise, they will be moved in Sad house which means if they are in Sad house until they go home, they will not be rewarded any stickers.

In a training session for new teachers, all teachers were told that every instruction given must be short and simple. The abbreviation for that was KISS that stands for "Keep It Short and Simple." It may look simple but T1 said that she still need s to think every class's characteristics before she teaches to figure out the simplest way of using the language:

\begin{abstract}
So, we need to set our mind like tune in. So we're going to talk like a... Okay let me put it in another way; if you want to meet the president, you need to prepare like some stuff before you present your ideas. The same here, so when you need to talk about like let's say 'sports' with 3, 4 or five year-old, you have got to think the simplest way, less complicated sentences. (T1 - Excerpt 4)
\end{abstract}

Rather than calling it short and simple use of language, T1 and T2 have a more specific term for this strategy, which is grading the language. They did it by using common words, using slower speed when talking as well as enunciating words to make them clear for the students as T1 and T2 stated during interviews:

Ok, so first of all we need to grade the language. This is like the most important thing because they are young. Definitely it's the most important thing. The second, we need to watch the speed of our speech, we definitely speak more slowly, more clearly and always check their understanding; OK? Thumbs up (giving an example). So it can help. (T1 - Excerpt 2)

and:

Well yeah I have to like, grade my English. So, I use common words, the high frequently used words. ...., (T2 - Excerpt 2)

Another strategy to ensure the students understanding was the use of gestures and facial expressions. In the videos, the teachers sometimes seemed to repeat a same word over and over. If we only listen to the voices or read the transcription alone, we might think that the words were repeated just so the students listen to the teacher. However, if we watch the video closely, gestures and facial expressions that accompanied the instructions might give different meaning to the word. 
In T2 class, she was teaching about body parts. After she showed the flash card 'arms' and said "arms" to present what the flashcard was. Then, she put down the flashcard and repeated the word "arms" while rubbing her arms to give information or a real example of arms and after that she asked her students to say "arms" and signaled the students touch their arms. At this step she then rubbed her arms again and said "arms" again in order to give an instruction to her students that they had to say "arms" and touch their arms at the same time. Those all steps were done only by using one word "arms" but being said multiple times.

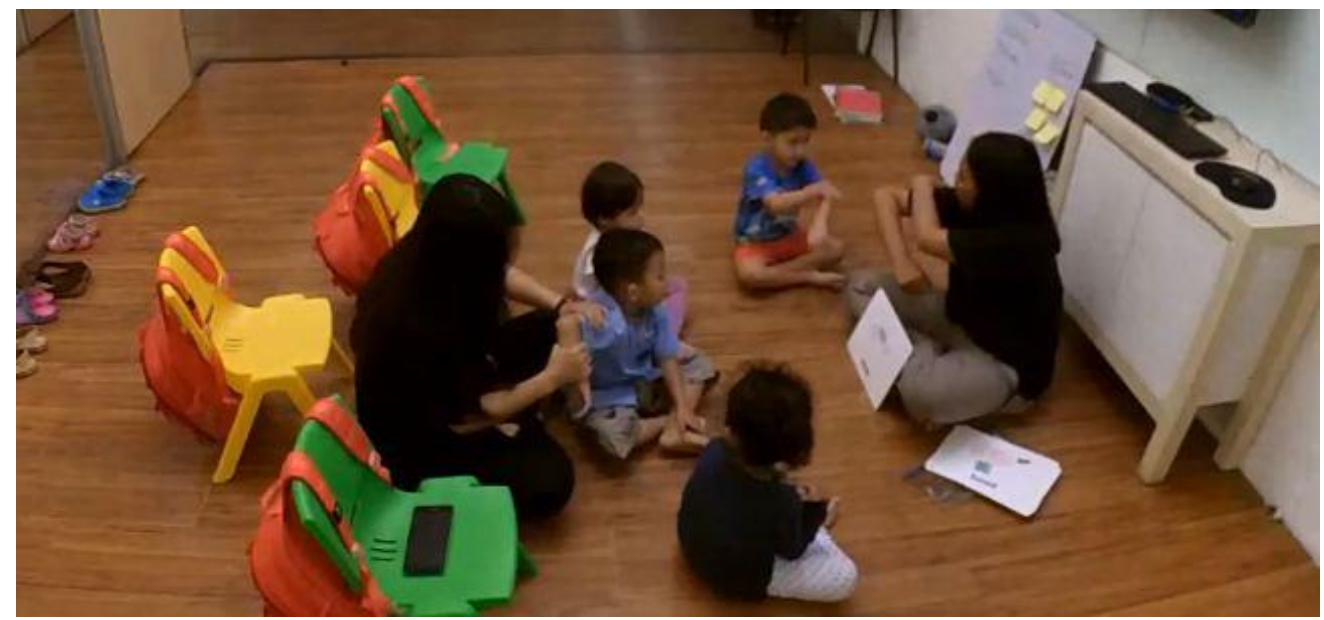

Figure 1. Using Gestures to Instruct the Student to Touch Arms

The picture above shows when T2 rubbed her arms to instruct her student (the boy in blue T-shirt) to touch or rub his arms while saying "arms". T2 also said in the interview that the use of gestures and facial expression is one of her strategies to make the students understand her:

.... And also I have to use extra gestures and facial expressions something like that. So to accompany instructions so they can fully understand. (T2 - Excerpt 2)

In addition to grading language and gestures, when T1 and T2 started or set up a new activity, they always demonstrated how the activity should be done properly. As an example, in T1's class the activity was a kind of musical chairs; so T2 explained that when the music was on, the students needed to pass the puppet (T2 passed the puppet while dancing) but when it was paused, the one who hold the puppet (it was given to the assistant) needed to get a color that T1 said. And the students needed to say "it's (color)" while tapping their head-thumbs up before they gave it to the teacher. So, T1 said to the assistant "red", the assistant ran and took the flashcard and gave it to T1 and said "it's ... (Touching her head) and red ... (gave two thumbs up) as can be seen in a picture below:

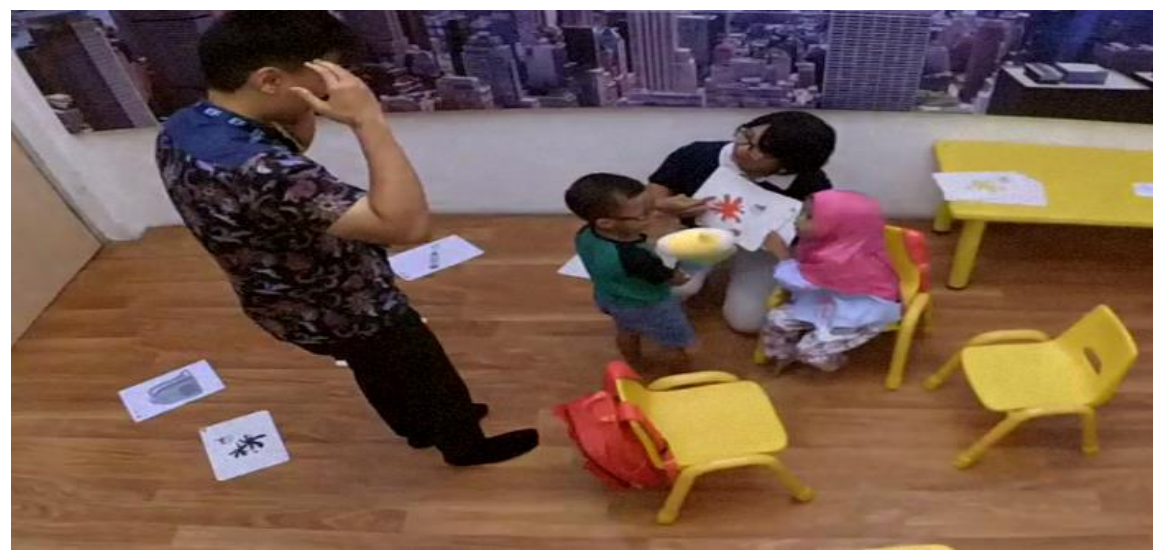

Figure 2. T1 Using the Help of an Assistant to Demonstrate an Activity 
SS classes have some routines that need to be done in every lesson. One of them is setting up rules for each class. The rules are same. They are; speak English, listen to the teacher and be nice. A lot of times teachers would demonstrate how the rules are. Some of them would use puppets when they set up rules in the beginning of the class. T2, for example, also agrees with that, using puppets to set up and demonstrate the rules. She did it in the class we observed when setting up the rules and she also said:

Even you have checked (students understanding). Mm, the students are very likely to say yes. So, you need to think of incorporating the demo; demonstrating how activities should be done, ideally. ..... So, you need to make sure like; "No, sit down first. Look - Sit down - and - be quiet. And Miss *** (T1) and Roddy will do this." So sometimes using a puppet can help. (T1 - Excerpt 6)

T2 also did the same in her class. She demonstrated how activities should be done by herself and she also said she often uses the help of an assistant she has when teaching to demonstrate activities:

\begin{abstract}
Yeah, using hand gestures. And then, that's pretty much it I think. Like grading the language, we have to use lots of gestures; we have to like give demonstrations how to do things. Because I have some very young learner classes, so I always have an assistant, so most of the time I will, you know like, give the demonstrations of doing the activities with the assistant first. So, they know how to do it. (T2 - Excerpt 6)
\end{abstract}

Looking at their similar responses in the interviews and actions in the videos, it turned out that they did not attend any special training that specifically focused on teaching VYLs, but they did attend some training about teaching YLs and about some teaching strategies. We also attended some training and we remembered one which was about classroom management with Rachel - but it was mostly about SS. In her training she gave examples of the use of puppets in setting up rules and how to deal with 'naughty' students. That's why we tried to remind T2 regarding that training because we remembered attending it with her. We asked:

So, was the training about SS the one with Rachel (reminding about the latest training)? (Researcher in T2 - Excerpt 19)

After that T2 started to recall the memories about the training and she was yessing my questions and also added that she had attended training about Child Development, the Milestones, which really helps her teach SS. As she stated below:

\begin{abstract}
Yeah, it helps me, it really helps me manage. Not manage, it really helps me teach my classes because after I attended that training that training with Fenty about child development and milestones. It is kind of give me of things I should expect and I shouldn't expect from the classroom. So I used to put so much pressure to myself like oh I teach SS because they don't behave or everything but it's not the student's fault neither is the teacher's fault. It's just the age thingy. So, it's like giving me ideas what to expect. So, like I had storytellers. Storyteller class was like crying. I knew that some of my students would cry, some would be ... want to be with their parents. So, it's kind of like things like that. Helps me manage my emotions, keep me calm, and you know it helps me teach the class better somehow. (T2 - Excerpt 22)
\end{abstract}

From some documents we had obtained, we found out that $\mathrm{T} 1$ and $\mathrm{T} 2$ were correct that there was not a training that specifically discussed VYLs except one; the one that T2 mentioned in the previous paragraph - about child development. But unfortunately we could not get the document because of confidentiality reasons. However, based on T2 explanation, the training was to give the understanding of child development skills from age 3 to 6 so that the teachers know what to expect from the students and hopefully can help them plan the lesson. The other training materials contain some activities for young, teen and adult learners as well as teaching strategies for teaching them. The materials, however, are not discussed in this study since they are not the focus of this study.

Although T1 and T2 did not get any special training related to VYLs, both teachers hinted that they learned so much about VYLs from sharing and discussion session with other teachers. One result of the discussion that started to catch on by the time the study started was the use of Happy and Sad houses to be used especially in SS 1 classes or the three-year old classes. We assume that the concept behind the houses is easier for the students to understand rather than telling them, and write the three rules explicitly and punish them if they violate the rules because most of them cannot read and write yet.

\title{
DISCUSSION
}

This fourth chapter of this article discusses the significances of the findings as reported in the third chapter. The discussion integrates the findings with the literature from chapter one under the following headings: the type of teacher talks used most in teaching VYLs and the strategies to make VYLs understand L2 directions. 


\section{The Type of Teacher Talks Used in Teaching VYLs}

From the class observation, it was known that the teachers did not use their first language at all, which is far different from other common ECE services in Sidoarjo that use L1 in teaching English (Astika, 2012; Nurhayati, 2014; Danuatmaja, 2016). It was done because they believe that three year old children can learn language faster than adults. It is supported by Brown (2000) who believed in CPH, which happens during two years old until early teens. The class was fine with the absent of the use of mother tongue. The mother tongue was only used when it really had to. It was done rarely and it was by the assistant, not the teachers since the use mother tongue in L2 language class will only spoil the very young learners to use their L1 again and again. That is why the use of mother tongue is seen as uncommunicative and pointless (Harmer, 2002). Still from the observations, there were 1827 utterances in L2 done by the teachers in their one-hour classes.

Before the observations, the teachers were asked about the use of English in their classes. T1 believed that in teaching VYLs, praising and encouraging students is the most prevalent among others and T2 believed that dealing with feeling is the most, which is quite interesting since from the previous studies mentioned in chapter one, they, praising and encouraging and dealing with feeling, have never been the first type of teacher talks used in all kinds of classroom setting. However, the results of the observations said differently, giving directions was the most used one in teaching VYLs. It similar to that of some research in primary schools setting (Pujiastuti, 2013; Kristianingsih, 2011), whose student age range is not far different from VYLs. When we asked them further about this just after we analyzed the data, both teachers thought that it might be because the repeated directions were actually one (same) direction so they thought they counted them as one and they might also want to make sure that the students understood the teachers' language well

The use of a lot of directions did not mean that the teachers gave different directions for the students in the class when doing activities. But they often used same directions, but they repeated them over and over or sometimes they paraphrased the directions. The teachers did it to make sure that the students understood what they wanted them to do. So, based on that, the repeated directions were a kind of efforts that the teachers did to communicate with students. For three-year old students who had never been exposed to English language before, the repeated directions could be the best way to successfully do it. And if it is, it will help achieve lesson aims (Seong, 2006). The teachers used giving directions when they wanted to set activities that involved some movements. To direct very young learners to do such activities will require a lot of directions or instructions that is probably why this is the most talk being used in the class. However, when setting up the activities the teachers not only used a lot of directions, they also provided some demonstrations or models for the students.

Different from giving directions which were done when the teachers wanted to set up moving activities., giving information, which was the second biggest talk used in this study, was used when the teachers wanted to present the target language to the students. It is still similar to giving directions, giving information was also done repetitively by the teachers. They did this to ensure that students got sufficient English language inputs so they could grasp the language easily and successfully (Fenclova, 2004; Jezkova, 2011). Because this might be the first time the students got exposed by the language, the teachers not only repeated the information but they also gave some visual aids like flashcards, gestures or realias. By doing that the teachers wanted to facilitate different kind of learners in grasping the information.

When directions or information have been given, teachers usually do not know if students really understand them or not. Then, teachers will usually ask something to check the students' understanding. Giving directions and giving information were done a lot so asking questions were also done a lot because the teachers checked the students understanding mostly by asking questions. That is why asking question was the third biggest among the seven talks. In asking questions teachers usually will use short questions and sometimes they also used facial expression to show that they were asking the students. T1 added in the interview that the questions were ICQ (Instruction Checking Question) as she stated below:

Oh yeah there is a term called ICQ: instruction checking question; if the instruction is not understood properly, then we need to re-do and repeat. So, that is probably what happened during the interview. (Excerpt $28-\mathrm{T} 1$ )

The fourth biggest talk was praising and encouraging. Every time the students acted like what the teachers wanted when they did something good, the teachers would praise them and encourage them to do more, for example when a teacher presented body parts and a student said the body parts, the teacher will him by saying "good job", "smart", etc. or even when a student does exactly what the teacher directs him / her to do, then the teacher will praise him. So, praising and encouraging was like asking questions whose occurrence always followed giving direction and giving information. These four biggest teacher talks are actually inseparable in these VYL classes. Their occurrence was like a chain reaction. What differed was giving directions and information were repeated over and over while the other two were not; the words used might be same for asking questions and praising and encouraging, but they were used in different occasion, not together at a time like a chain.,

While the other talks were used not that much since in my opinion they are not really related to the core teaching activity, they are more related to the management of the students, for example, criticizing behavior which was done only when students misbehaved. Again, the teachers were also helped by the use of two houses in criticizing student behavior namely happy and sad house, which might be why they did not spend many words in criticizing. They were constantly applied routines 
(Shin, 2006) that encourage the students to follow some class rules; speak English, listen to the teacher and be nice. So, when they did misbehave, they would be moved out of Happy House to stay in Sad House.

Another less frequently used talk was using the ideas of the students. The use of this talk was only when the students saw options and they needed or just wanted to choose over the others, for example when students were shown a target language which was modeled by using puppets, which frequently happened in hoping that the very young visual learners learned by simply watching it (Majaron, 2011). They sometimes wanted to imitate the presentation, they would ask if they needed to use Roddy or another (Roddy is one of five characters in SS book). That time the teachers would use students' ideas by yessing the request or another possible conditions that usually happen in this course are when teachers ask if students want to do an activity on the floor of by sitting on the chair, who plays / practices first (mostly when the activity involves movement), if they want stars or diamonds as a reward, etc.

The least talk used was dealing with feelings. Perhaps, it was because the students did not know what to say in English while the class rules forbade them to use their L1. Teachers in this course, in my experience, usually do this before we come in to the classroom. We are to wait in the lobby about five minutes or more before a SS class starts. During this time, we are allowed to talk to the parents or even talk to students using L1 if necessary. From this we can know what the parents want and most of them argued that learning L2 sooner is better just like what Jazuly \& Indrayani (2018) found. The students also talk about their feeling more in this session, it could be about new items they have, what they did at home and many more, but when we start to line up and become a train and march together to the class the students already know that this time only English applies because again it is another routine that we have to encourage students to use English (Shin, 2006) in EF. That is possibly why dealing with feeling was the least since to tell teachers about what they feel is hard because it requires students to know more vocabulary items that they might not have known. So far, the teachers only discussed students' feeling in the beginning of the lesson or responded to what they said or asked "i don't know", "Oh yeah, I know it (when a student showed a teacher his / her new thing). “”

\section{The Strategies to Make VYLs Understand L2}

The obvious strategy that the teachers used was repetitions of giving directions, information and asking questions. The teachers said that they wanted to make sure that their students understood what they had said and also they thought that it was a kind of automatic response when they gave directions and if the students seemed not to get it, then they automatically reinstructed them. But in my opinion, the teachers tried to give a clearly staged set of presentation when they did it. So, first the teacher showed what it was and then they made sure that everybody listened so they repeated the information again and again. Afterwards, the teachers wanted to clarify if the students understood so they asked what is so called ICQs to clarify their understanding and of course the ICQs were often the same words, and then they wanted to activate or apply the words the students had learned by doing some physical activities. To do it, the teachers needed to direct the students so, they gave directions and after that, the same cycle happened again with minor differences depending on problems occurring during the execution. So, it is clearly that the teachers used their talk to scaffold the lesson in such a way that the students could understand it easily. It is in line with Kim \& Ko who stated that teacher talks play an important role in scaffolding.

In VYLs classes, the teacher talks used were never long. They were always short and simple. So, it is almost impossible if the teacher talks worked alone in the teaching activities in the classes. In their teaching activities the teachers applied some strategies to get the students understand the target language. One of them was the use of gestures. Gesture is a critical medium, particularly for very young learners, who still rely on body language and facial expression to communicate (Reilly \& Ward, 2017). Body language and facial expressions were often used to accompany the teacher talks in the class. It gave students visual aids of what an arm is (as illustrated in Chapter III). Besides, in second language memorization, when a student wants to learn a new vocabulary, s/he will try to make connection in his / her head about the vocabulary being learned. In other words by using gesture, a teacher has given another connection to the vocabulary. As a result, the student will recall the vocabulary easier because s/he has a richer trace left in his / her memory about the vocabulary (Tellier, 2008). Similar things also happened in the classes when both T1 and T2 touch their head and the students recalled that they need to say "it's" and when T1 and T2 touched their shoulder, the students said either "a" or "an", finally the teachers touched the target language which was "arm". If the target language was an adjective that generally does not need an article, then only the head was touched which means "it's", without touching shoulder and the touch an object that had the adjective (table for "red"). That was what happened in T1's class which studied about colors.

After the vocabulary was presented, the next step was to activate and apply the vocabulary in an activity. The activity mostly required students to do something involving body movements and then they used the language while they were moving. Since the activity involved movements the direction being given should be clear, the directions, consequently, needs to be given clearly. In this step, the teachers often broke down the directions and the students did one step at a time. It is like what Rebecca, et al. (2015) stated. She said that directions should be given step by step and teachers should keep reminding the students what to do in each step.

Not only did the teachers break down the directions, they also modeled or demonstrated how it should be done. The reason for that was that if the teachers only explained what should have been done, it would be laborious. That was why the teachers modeled the activity because most people learn observationally through modeling; from observing others (Salisu \& 
Ransom, 2014). So, the teachers performed an idea of how a new activity was performed, and on later occasions this coded information serves as a guide for action for the students. Sometimes the teachers also did it differently; they used the help of an assistant to demonstrate an activity. By looking at the assistant demonstrating the activity, the students usually would feel more comfortable since the assistant was more like their friend rather than the teacher. The assistant sometimes also made a mistake where the students might know what was right. It was done to give feeling that it was okay to make a mistake in the class.

Besides the help of an assistant, the teachers also used puppets a lot. The puppets were Roddy (a three-year old boy in a green T-shirt), Mel (a three year old blue bird), Kev (a three-year old green frog with goggles), Ben (a three-year old brown bear) and Vic (a three-year old red hedgehog). The teachers usually use a puppet to establish rules in the beginning of the class; the teachers would ask the puppet if it could do or break the rules. The puppet was also given a star if it did well and lost a star if it did the otherwise. Using a puppet in VYL class is really helpful. Students feel like they are playing instead of studying and they usually feel more relaxed (Caganaga \& Kalmis, 2015) when they make a mistake while they use puppet rather than when they did it without a puppet because they think it is funny. It might be because students become more comfortable and open up with the help of puppets (Mishina \& Wallace, 2004), thus increasing students' dialogue effectively. It also often happens in here when a quiet student starts to become more open after being given a puppet.

Another surprising but not-related finding was that both teachers did not get any special training related to VYLs teaching. At first, we thought they did since T1 and T2 were often sent to the headquarter to have a training about SS teaching. However, from the interviews we found that the training was not really about teaching SS like teachers being given any methods or strategies in dealing with VYLs. But it was not, the only training about teaching VYLs was the one being given to first year teachers which discussed about VYLs classroom management and it was only about setting up routines in the class because young learners work well within a structured environment and enjoy repetition of certain routines and activities (Shin, 2006).

I crosschecked with training materials that all teachers had joined and there was only one discussing about VYLs. It focuses on VYL skill development. The training was done so teachers know what to expect from three-to-six-year-old children and how to deal with their parents when teachers have SS Parent Teacher Meeting (PTM) since some issues regarding parents' expectations rose just before the training was held. The training that $\mathrm{T} 1$ and $\mathrm{T} 2$ often attended turned out that it was discussion forum between teachers regarding SS teaching and they tried to solve it together. Perhaps, the absence of special training related to SS was because until now there is no pre-service training in Indonesia that specially prepares teacher to teach both English and VYLs so that there are not any people who master in both area, English and VYL teaching and it becomes too risky for someone to give that kind of training for the teachers.

\section{CONCLUSSIONS}

From the findings, it is know that teachers used L2 only in teaching very young learners. The language used has two functions. One is used to teach; teachers delivered the topic materials related to English language, it can be vocabulary, grammar, etc. In doing this, both teachers used four types of teacher talk namely giving directions, giving information, asking questions and praising and encouraging. These four types of talk were used in a set of instructions; giving information was used to present the materials, asking questions was used to check the students understanding, giving instructions was used to present some activities which were then checked by asking questions and praises and encouraging was used to reward students.

The other one is used to manage students' behavior. In this functions, there were three types of talks which were used namely criticizing behavior, using ideas of students and dealing with feeling and the occurrence of each type was a few. It might be because the students had been familiar with the class rules that both teachers use. In addition, the language used was also accompanied by gestures and demonstrations to give more clues to the students so they can understand the L2 easier.

It is a fact that very young learners learn language better than other age groups of learners so it is such a waste to teach another language to them using the mother tongue. It does not help the students to use the language better since they do not really get sufficient exposure of the target language. Again, teaching vocabulary and daily expressions without giving a clear context would be confusing for very young learners. We suggest that other ECE services start to consider using the target language (English) as a teaching medium.

\section{REFERENCES}

Astika, G. (2012). Teacher and Child Talk in 'Paud' English Class. TEYLIN, (pp. 46-58).

Atmowardoyo, H. (2018). Research Method in EFL Studies: Descriptive research, Case Study, Error Analysis, and R \& D. Journal of Langhuage Teaching and Reseach, 9(1), 197-204.

Brown, H. D. (2000). Principles of Language Learning and Teaching. New York: Longman.

Bryman, A. (2008). Social Research Methods. New York: Oxford University Press.

Caganaga, C. K., \& Kalmis, A. (2015). The Role of Puppets in Kindergarten Education in Cyprus. Open Access Library Journal. Chang, M. C., Dunkelberg, E., Iskandar, S., Naudeau, S., Chen, D., Cibulskis, R., et al. (2006). Early Childhood Education and Development in Indonesia: An Investment for a Better Life (English). Washington DC: World Bank.

Danuatmaja, N. A. (2016). Kindergarten Teacher's Views toward The Code Switching Strategy. Salatiga: Satya Wacana Christian University. 
Febiarachmah, S. F., \& Susanto. (2017). Teacher Talk for Instruction In English Foreign Language Class. RETAIN, $407-415$.

Fenclova, M. (2004). Jayzkova Propedeutika Pro Zakladni Skolu Aneb Kudy Do Evrpske Multilingvni Budoucnosti. Pedagogika, 251-260.

Jazuly, A., \& Indrayani, N. (2018). Guidance of Teaching English to Young Learners (TEYL) for Early Childhood Education Teachers at Ad-Dhuha Kindergarten of Jember. Journal of Linguistics, English Education and Art (LEEA), 1(2),168179. https://doi.org/10.31539/leea.v1i2.175

Kristianingsih, C. (2011). The Comparison of Teacher Talk in The English Learning Teaching Process Among Three Different Levels: Elementary, Junior and Senior High Schools in Bantul in The Academic Year of 2009/2010-2010/2011. Unpublished Thesis. State University of Yogyakarta,. Yogyakarta.

Majaron. (2011). Art as a Pathway to the Child. European Affective Education Network (EAEN).

Meida, S. N., \& Fadhly, F. Z. (2018). The Analysis of Teacher and Students Talk In Indonesian Efl Classroom. Indonesian EFL Journal, 4(1), 73-81.

Mishina, L., \& Wallace, A. (2004). Relations between the Use of Puppetry in the Classroom, Student Attention and Student Involvement. Brooklyn: Brooklyn College.

Nasir, C., Yusuf, Y. Q., \& Wardana, a. A. (2019). A Qualitative Study of Teacher Talk in an EFL Classroom Interaction in Aceh Tengah, Indonesia. Indonesian Journal of Applied Linguistics, 8(3), 525-535. https://doi.org/10.17509/ijal.v8i3.15251

Nurhayati, L. (2014). The Implementation of English Teaching and Learning Process in Early Childhood Education Centers in Daerah Istimewa Yogyakarta (DIY). State University of Yogyakarta, Yogyakarta.

Pangesti, D. (2016). Teacher Talk in English Teaching and Learning Process at SMK Batik 1 Surakarta in 2015/2016 Academic Year. Surakarta: Muhammadiyah University of Surakarta.

Pujiastuti, R. T. (2013). Classroom Interaction: An Analysis of Teacher Talk and Student Talk in English for Young Learners (EYL). Journal of English and Education, 1(1), 163-172.

Reilly, V., \& Ward, S. M. (2017). Very Young Learners (Resource Book for Teachers). London: Oxford University Press.

Rosiek, J. (2003). Emotional Scaffolding: An Exploration of the Teacher Knowledge at the Intersection of Students' Emotion and the Subject Matter. Journal of Teacher Education, 54(5), 399-412.

Salisu, A., \& Ransom, E. N. (2014). The Role of Modelling towards Impacting Quality Education. International Letters of Social and Humanistic Sciences, 32, 54-61.

Seong, G. B. (2006). Teacher Talk Revisited: Issues, Findings, and Future Directions. International Letters of Social and Humanistic, 63-90.

Shin, J. K. (2006). Ten Helpful Ideas for Teaching English to Young Learners. English Teaching Forum, 2-13.

Silverman, R. D., \& Hartranft, A. M. (2015). Developing Vocabulary and Oral Language in Young Children. New York: London The Guilford Press.

Singleton, D., \& Ryan, L. (2004). Language Acquisition: The Age Factor. Clevedon: Multilingual Matters Ltd.

Sofyan, R. R., \& Mahmud, M. (2014). Teacher Talk in Classroom Interaction: A Study at an English Department in Indonesia. ELT Worldwide, 1(1), 45-58.

Tellier, M. (2008). The Effect of Gestures on Second Language Memorization by Young Children. John Benjamin Publishing, 219-235. 